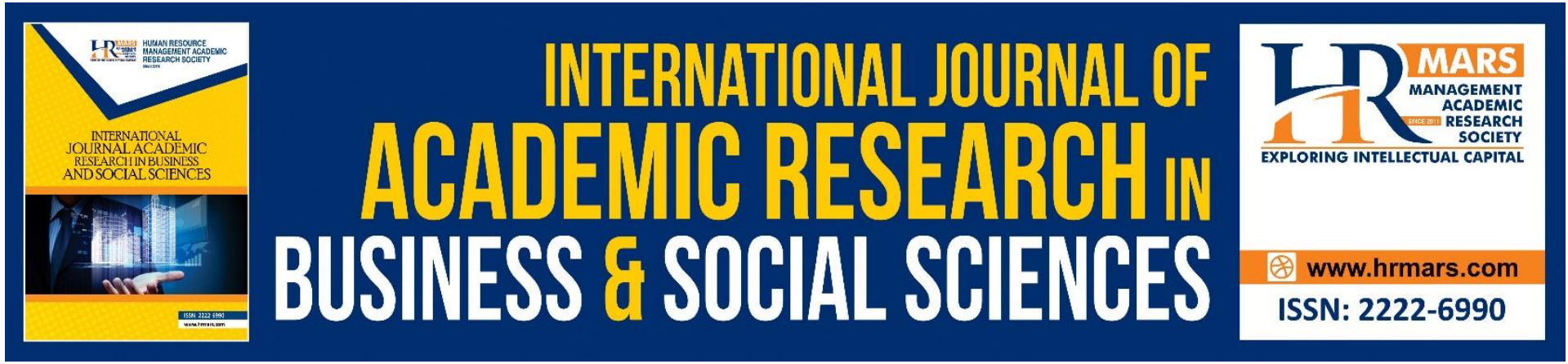

\title{
Integration of Parental Monitoring and Parental Communication Factors on Deviant Behaviours of Adolescents in Peninsular Malaysia
}

Syazwana Aziz, Salina Nen, Suzana Mohd Hoesni \& Jamiah Manap

To Link this Article: http://dx.doi.org/10.6007/IJARBSS/v11-i7/10565

DOI:10.6007/IJARBSS/v11-i7/10565

Received: 18 May 2021, Revised: 22 June 2021, Accepted: 09 July 2021

Published Online: 26 July 2021

In-Text Citation: (Aziz et al., 2021)

To Cite this Article: Aziz, S., Hoesni, S. N. S. M., \& Manap, J. (2021). Integration of Parental Monitoring and Parental Communication Factors on Deviant Behaviours of Adolescents in Peninsular Malaysia. International Journal of Academic Research in Business and Social Sciences, 11(7), 984-1002.

Copyright: @ 2021 The Author(s)

Published by Human Resource Management Academic Research Society (www.hrmars.com)

This article is published under the Creative Commons Attribution (CC BY 4.0) license. Anyone may reproduce, distribute, translate and create derivative works of this article (for both commercial and non-commercial purposes), subject to full attribution to the original publication and authors. The full terms of this license may be seen

at: http://creativecommons.org/licences/by/4.0/legalcode

Vol. 11, No. 7, 2021, Pg. 984 - 1002

Full Terms \& Conditions of access and use can be found at http://hrmars.com/index.php/pages/detail/publication-ethics 


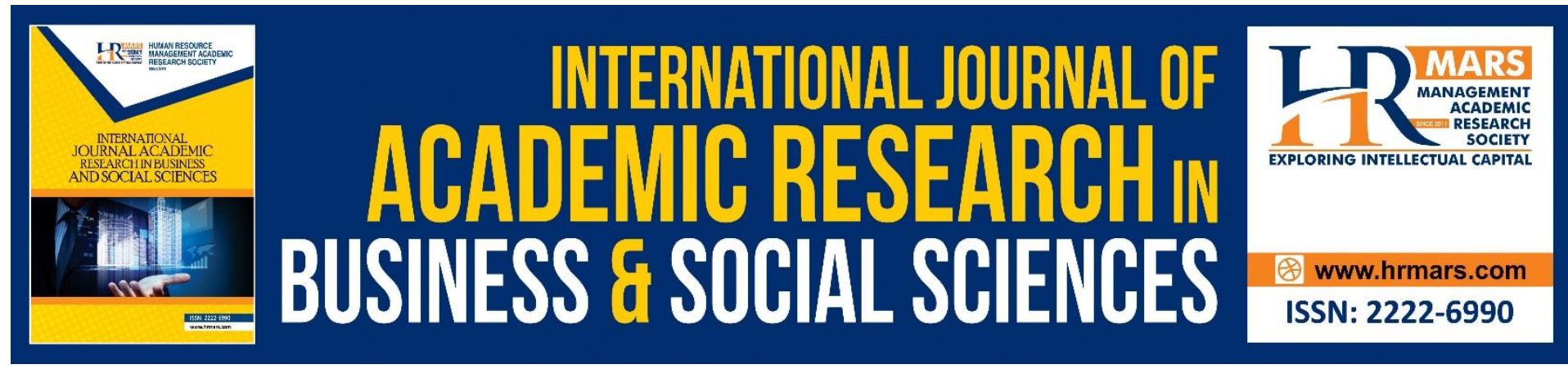

\title{
Integration of Parental Monitoring and Parental Communication Factors on Deviant Behaviours of Adolescents in Peninsular Malaysia
}

\author{
Syazwana Aziz, Salina Nen, Suzana Mohd Hoesni \& Jamiah \\ Manap \\ School of Psychology and Human Development, Faculty of Social Sciences and Humanities, \\ The National University of Malaysia (Universiti Kebangsaan Malaysia)
}

\begin{abstract}
This research aimed to study the factors for parents' monitoring and parents' communication and their effects on deviant behaviours among adolescents in Peninsular Malaysia. This study utilized a mixed mode design which are Simultaneous Triangulation Design for the quantitative data; and qualitative data. Findings from the quantitative data established that parents' monitoring negatively correlates with adolescents' deviant behaviour. Whereas, parents' communication did not present any significant relationship with deviant behaviour from adolescents. From interviews relating to parents' monitoring, two sub-themes were identified which are the lack of monitoring of the child's activity and perception of parents' monitoring. The sub-themes uncovered from the interview on parents' communication were three which are communication between parents and child, conflict of communication, and the perception on the importance of communication. The result from the integration of data on the factors for parent's monitoring is paralleled and the qualitative data supported the quantitative data. Whilst the finding from the integration of data on parents' communication was different, qualitatively, it was found that poor communication between parents and their child will lead to deviant behaviour. In conclusion, parent's monitoring plays an important role in ensuring that adolescents do not get involve in deviant behaviour. Good monitoring makes adolescents feel that they are given enough attention and feel guilty if involved in deviant behaviour. Good communication from the parents help to improve adolescents' creativity, ideas, and allow for effective two-way communication between parents and child. Further, adolescents feel the need to be more rationale and even avoid from participating in deviant activities.
\end{abstract}

Keywords: Adolescents, Deviant Behaviour, Parents' Monitoring, Parents' Communication

\section{Introduction}

This study focuses on the issue of deviant behaviour that occurs among adolescents in Peninsular Malaysia. The term deviant in deviantology and psychology is defined as repetitive behaviour that violates social norms, does not conform to conventional values and rules, negatively evaluated by others, and also actions that can harm oneself and others 
(Dvoryanchikov et al., 2020). According to scholars, deviant behaviours consist of two main forms, namely physical and verbal (Pepler, 1988).

Smith \& Thompson (1991) mentioned that physical deviant behaviour includes physical intimidation or violence, kicking, hitting, pushing, injuring, killing, raping and taking or destroying other people's property. When it comes to verbal deviant behaviour, it was said to include name-calling, ridicule and spreading. More often, Individuals involved in these deviant behaviours are those who have been labelled negatively by society (Nalah et al., 2013). This deviant behaviour means behaviours that violates social norms; hence, individuals who have been negatively evaluated by others tend to behave aggressively which involves acts of physical and verbal harm that have a negative impact on the individual as well as society.

Social issues among adolescents are a phenomenon that causes a conscern among Malaysians of today. These social issues involve deviant behaviours that result in decrease in moral values that coincides with learning difficulties in school, dropping-out of school, and juvenile cases among adolescents. Institut Penyelidikan Belia Malaysia (2010) conducted a study on social problems; specifically, those which involve deviant behaviours in Malaysia. Out of 2,403 respondents, $94 \%(n=2249)$ have conducted at least one risky behaviour out of the stated five dimensions which are sexual, substance abuse, rule-breaking, integrity, criminal.

A study by Ezhar et al (2007) found that the most common social problems among adolescents are hanging out (80\%), breaking curfew (68\%), smoking (50\%), bullying (24\%), and illegal racing (23\%). All these behaviours are considered as deviant behaviours as they deviate from societal norms (Delibalt et al., 2017). Hence, the statement "at least once" on the involvement in risky behaviour is proof that deviant behaviours is a critical issue that must be studied in detail. Particularly, because it concerns the future generation.

Past studies have shown various factors that have influenced deviant behaviour among adolescents. These include familial background, peer influence and community risk factors involving school policy. Furthermore, when adolescents engage in risky behaviours such as alcohol consumption and sexual relationships, it relates with the fundamental value of their relationships with their family as well as peer influence (Shader, 2001). Thus, the risk factors that have been identified to contribute to deviant behaviours among adolescents based on previous studies involve social factors, community factors, mass media, economy, urbanization, cultural factors and identity crisis (James et al., 2005)

The research problem identified for this study focuses on social factors; specifically, the study of parental monitoring and parental communication towards adolescents with deviant behaviour. Parental monitoring factors were given attention in this study because the failure of parents to monitor their children's daily activities made them feel free to try to commit any deviant behaviour as they felt empowered to act outside the boundaries of societal norms. The proposal of this study is supported by Ismah et al., (2015) who suggested that future studies focus more on the important role of parents in monitoring children's behaviour. In fact, parents need to monitor their children's regardless of gender (Garner et al., 2010). 
According to Muhwezi et al (2015), in urban and rural areas of Uganda, poor monitoring and communication by parents led to an increase in deviant behaviours among adolescents. Stattin and Kerr (2000) suggested that parents should increase the monitoring of their children's movements, and build a good environment so that children are comfortable to confide of their daily activities. This supports the need for studies related to parental monitoring factors on children's daily activities in order to identify the extent to which they influence deviant behaviour among Malaysian adolescents today.

A study by Sajad et al (2012) found that parental monitoring was not considered a predictor of adolescent deviant behaviour; but it was relevant to their children's peer selection. This is due to the child seeking for the opportunity to meet their peers who misbehave without parent's supervision (Dishion et al., 1995). This statement is supported by a study conducted by South Australia Department of Justice as discussed by Sajad et al., (2012) that found that adolescents that are not supervised by their parents tend to look for personal freedom. It suggests that although parents' monitoring may not directly relate to deviant behaviours among their children, adolescents are still free to be friends with deviants are not monitored by their parents.

Another factor that are considered critical in this study is parental communication and how it causes adolescents to interact less with their parents when approached negatively. Recently, communication and advice from parents to their children lean more towards Sejak kebelakangan ini, kebanyakan komunikasi atau pesanan ibu bapa kepada anak-anak lebih berasaskan pesanan yang berunsur threats, warnings and verbal abuse (Muhwezi et al., 2015). Communication in the form of threats and warnings makes children feel uncomfortable to interact with their parents. According to Guzman and PohImeier (2014), parents who emphatically listen to the problems and value the ideas from their children are able to form more effective parental communication with the child

Past studies have also found that parental communication is a factor that can decrease adolescents' engagement in deviant behaviours. For instance, a study by Mena et al (2008) found Hispanic adolescents who reported their daily activities showed no negative behavioural reactions; communicated positively about sexual knowledge; and the female participants were more open communicating about moral issues. Lytle et al (1999) are of the opinion that more appropriate subsequent studies examine the effects of parental communication with deviant behaviours among adolescents. Therefore, this study will also examine in-depth the factors of parental communication in shaping positive behaviour or vice versa.

Therefore, there are three objectives in this study which are:

1) To study the factor for parental monitoring and communication on deviant behaviour among adolescents in Malaysia.

2) To explore the factor for parental monitoring and communication as causes of deviant behaviour among adolescents in Malaysia.

3) To elaborate the factor for parental monitoring and communication on deviant behaviour among adolescents in Malaysia based on quantitative and qualitative data. 


\section{Methodology}

The design that was utilized for this study is mixed method research design. The reason for this choice is due to the use of integration of qualitative and quantitative method where the findings will be different or relate to one another (Creswell, 2014).

The selection of the mixed-method research design of this study is in line with previously mentioned objective which is to study, explore and determine the factors that influence deviant behaviour among adolescents in Malaysia. The Concurrent Triangulation Design was the strategy and approach for this mixed-method design (Creswell, 2009). Creswell (2009) explained that when using this integrated design, the qualitative and quantitative data are collected simultaneously and they are compared in order to observe differences and similarities in the findings. Figure 2.1 is a visual representation of the design chosen for this study.

QUANTITATIVE

(Data collection: Survey)

- Variable parental monitoring

- Variable parental communication
QUALITATIVE

(Data collection: Case Study)

-Factor for parental monitoring -Factor for parental communication



QUANTITATIVE

Data analysis

(Inferential analysis)

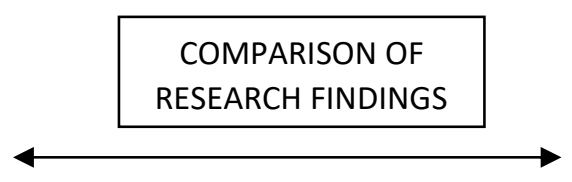

QUALITATIVE

Data analysis

(Thematic analysis)

Figure 2.1 Research design: The Concurrent Triangulation Design (Creswell 2009)

The population and sampling of this study used clustered random sampling (quantitative) and purposive sampling (qualitative). A total of 299 respondents for the quantitative study; and 8 study participants for the qualitative study aged 13 to 21 years were selected. They were selected based on the criteria of adolescents involved in deviant behaviour from five juvenile detention institutions (Sekolah Tunas Bakti) around Peninsular Malaysia. Table 1 shows the sampling framework of this study based on a mixed study design. 
Table 1. The sampling framework by zone and state

\begin{tabular}{|c|c|c|c|c|c|c|}
\hline ZONE & State & Population & $\begin{array}{l}\text { Sampling } \\
\text { framework } \\
\text { phase } \\
\text { Quantitative }\end{array}$ & 1: & $\begin{array}{l}\text { Sampling } \\
\text { framework } \\
\text { phase } \\
\text { Qualitative }\end{array}$ & 1: \\
\hline \multirow[t]{3}{*}{$\begin{array}{l}\text { Southern } \\
\text { zone }\end{array}$} & $\begin{array}{l}\text { 1. Sekolah Tunas Bakti } \\
\text { Sungai Lereh, } \\
\text { Melaka (Female) }\end{array}$ & 180 & 50 & & 4 & \\
\hline & $\begin{array}{l}\text { 2. Sekolah Tunas Bakti } \\
\text { Sungai Besi, } \\
\text { Selangor }\end{array}$ & 823 & 62 & & 4 & \\
\hline & $\begin{array}{l}\text { 3. Sekolah Tunas Bakti } \\
\text { Taiping, Perak }\end{array}$ & 237 & 64 & & & \\
\hline $\begin{array}{l}\text { Northern } \\
\text { zone }\end{array}$ & $\begin{array}{l}\text { 4. Sekolah Tunas Bakti } \\
\text { Telok Air Tawar, } \\
\text { Pulau Pinang }\end{array}$ & 377 & 60 & & & \\
\hline $\begin{array}{l}\text { Eastern } \\
\text { zone }\end{array}$ & $\begin{array}{l}\text { 5. Sekolah Tunas Bakti } \\
\text { Marang, } \\
\text { Terengganu } \\
\text { (Female) }\end{array}$ & 119 & 63 & & & \\
\hline & JUMLAH & 1736 & 299 & & 8 & \\
\hline
\end{tabular}

The research instruments utilized for the mixed method design of this study was a questionnaire which addressed deviant behavior variables: parental monitoring and communication. Meanwhile, interview was conducted for qualitative data. The description of the study instruments are as follows:

Youth at Risk Screening Questionnaire (YRSQ), designed by (Conner, 2003). The accuracy for this instrument is assured as it is used by the Social Welfare Department (JKM) all over Malaysia. JKM (2010), explained that YRSQ contains 51 items and every item has its own value. This instrument uses dichotomous marking, where the respondent will mark (/) in the "YES" box if he has ever committed the deviant behavior. One item answered "YES" equals to 1 mark. The alpha Cronbach value for all items is 0.903 (Roszita, 2010).

Inventory Parental Monitoring Scale (IPMS) was designed by Capaldi and Patterson (1989) that is meant to measure the perception of children towards their parents, the set of rules by the parents, and the effectiveness of parenting to children. The suitability of the use of this test tool is for children aged 10 to 21 years (Stattin \& Kerr, 2000). This instrument contains 9 items and uses scoring based on 5-point Likert scale measurements namely (1) Never, (2) Rarely, (3) Sometimes, (4) Often and (5) Always. The reliability value of this test tool based on previous studies is .86 (Stattin \& Kerr, 2000) and .84 (Jaccard et al., 2010).

Revised Family Communication Pattern (RFCP) by Ritchie and Fitzpatrick (1990) was also adapted. This instrument has two dimensions that describe the structure of the family, namely the dimension of socio -orientation (conformity) and the dimension of conceptual orientation (conversation). This instrument contains 25 items of which 15 items are composed 
of conversational orientation (items 1 to 15 ) and 10 items are composed of conformity orientation (items 16 to 25). The measurement scale is using Likert scale rating which is 1 (Never), 2 (Rarely), 3 (Sometimes), 4 (Often) and 5 (Very often). The reliability values of this test tool based on previous studies are .93 (Ritchie \& Fitzpatrik, 1990), .82 (Spirito et al., 2015) and .89 (Guilamo-Ramos et al., 2017)

Interview instrument- A total of 11 interview items were constructed for the purpose of case study exploration, namely 6 items were of questions for parental monitoring factors and 5 items were of questions for parental communication factors. All items of this question set were tested for validity from experts in the field based on the Kappa Index agreement reliability value (Landis \& Koch, 1997) with a reliability value of 1.0 (Very good).

\section{Findings}

The findings of this study show the reliability value of the instruments used for this study, the quantitative data to achieve the first objective and the qualitative data to achieve the second objective.

The reliability value for the test instrument (YRSQ) with 51 items tested using Cronbach's Alpha technique is $\alpha=0.904$. The parental monitoring test tool (IPMS) with 9 items obtained a reliability value of $\alpha=0.797$. The reliability value obtained by the parent communication test tool, namely the RFCP with 25 items obtained $\alpha=0.884$.

\section{Findings of the Quantitative Study}

Hypothesis 1: There is no significant relationship between parental monitoring and deviant behaviour among adolescents in Peninsular Malaysia

\begin{tabular}{llll}
\hline & & Deviant behaviour & Parental monitoring \\
\hline \multirow{3}{*}{ Deviant behaviour } & Pearson & 1 & $-.153^{* *}$ \\
& Correlation & & 0.008 \\
& Sig. (2-tailed) & & 299 \\
\hline
\end{tabular}

**. Correlation is significant at the 0.01 level (2-tailed).

The results showed that there was a significant negative relationship between parental monitoring and deviant behaviour $(r=-0.153, p=0.008<0.01)$. The study hypothesis was rejected because there was a significant negative relationship between parental monitoring and adolescent deviant behaviour. Based on the strength of the correlation between parental monitoring and deviant behaviour, it is of weak negative correlation Szilvia (2011). The negative correlation, on the other hand, indicates that the higher the degree of parental monitoring, the lower the level of adolescent deviant behaviour.

The findings of this study are supported by the findings from Borawski et al (2003); Ross-Gray (2020); Fosco et al (2012) who found that there was a negative relationship between parental monitoring and deviant behaviour. In essence, high parental monitoring can reduce the level of adolescent deviant behaviour. Haapasalo and Tremblay (1994) found that adolescents aged 13 to 14 , who received good parental monitoring, and rarely fought with peers showed less involvement in deviant behaviour. The supportive effects of parental monitoring can reduce deviant behaviours, and deviant peers throughout adolescent development (Barnes et al., 2006). Keijsers (2015) found that the adolescents in their study 
spent a lot of time with friends and receive less parental monitoring with regards to their child's activities at all times. Lack of parental monitoring of children's activities gives them opportunities to engage in deviant behaviours (Stattin, 2000). Hence, parental monitoring is the most important factor in ensuring that the developmental stage of adolescents is not influenced by behaviours that deviate from societal norms or these deviant behaviours.

Hypothesis 2: There is no significant relationship between parental communication and deviant behavior among adolescents in Peninsular Malaysia.

\begin{tabular}{llll}
\hline & & Deviant behaviour & Parental communication \\
\hline \multirow{3}{*}{ Deviant behaviour } & Pearson & 1 & 0.009 \\
& $\begin{array}{l}\text { Correlation } \\
\text { Sig. (2-tailed) }\end{array}$ & & \\
& $\mathrm{N}$ & 299 & 0.873 \\
& & 299 \\
\hline
\end{tabular}

**. Correlation is significant at the 0.01 level (2-tailed).

The findings of the study showed that there was no significant relationship between parental communication and deviant behaviour among adolescents $(r=0.009, p=0.873$ > $0.05)$. A significant value greater than 0.05 meant that the hypothesis was accepted where there is no relationship between parental communication and deviant behaviour among adolescents in Peninsular Malaysia.

The findings of this study are supported by the study of Ennett et al (2001) who found that there was no relationship of parent-child communication on adolescent deviant behaviour. Nevertheless, the study of Miller et al., (1998) found a weak correlation for parental-child communication factors on risky behaviours. The differences in support of the findings of this study indicate that the communication factors of parents with children are still in the intermediate stage that may or may not affect on adolescent deviant behaviour. This is because the communication conveyed by parents to children is likely to differ based on how the adolescent defines them (Guilamo-Ramos et al., 2006). Researchers have argued that parental communication factors are different according to the manner of acceptance by the child and good communication will help them more easily make the right choices in the actions they take.

\section{Findings of the Qualitative Study}

This section covers the findings with regards to the background of the respondents. Table 2 shows the descriptive statistics of the participants of the study according to their current juvenile centres and deviant behaviours commited. 
Profiles of Adolescents Involved in Deviant Behavior

\begin{tabular}{|c|c|c|c|c|c|c|c|c|c|}
\hline Respondents' profile & K1 & $\mathrm{K} 2$ & K3 & K4 & K5 & K6 & K7 & K8 & \\
\hline \multicolumn{10}{|l|}{ State } \\
\hline Melaka & 1 & & & & & & & & 1 \\
\hline Johor & & 1 & & & & & & 1 & 2 \\
\hline Selangor & & & 1 & & 1 & & & & 2 \\
\hline Kelantan & & & & 1 & & & & & 1 \\
\hline Pahang & & & & & & 1 & 1 & & 2 \\
\hline \multicolumn{10}{|l|}{ Gender } \\
\hline Male & & & & & 1 & 1 & 1 & 1 & 4 \\
\hline Female & 1 & 1 & 1 & 1 & & & & & 4 \\
\hline \multicolumn{10}{|l|}{ Age } \\
\hline 14 years old & & & & & 1 & & & & 1 \\
\hline 15 years old & & & & 1 & & 1 & & & 2 \\
\hline 17 years old & 1 & & 1 & & & & 1 & 1 & 4 \\
\hline 20 years old & & 1 & & & & & & & 1 \\
\hline \multicolumn{10}{|l|}{$\begin{array}{l}\text { Deviant behaviour } \\
\text { commited }\end{array}$} \\
\hline Drugs & 1 & 1 & 1 & & 1 & 1 & 1 & 1 & 7 \\
\hline Smoking & 1 & 1 & & & 1 & & 1 & & 4 \\
\hline Alcohol consumption & & 1 & & & & & & & 1 \\
\hline Stealing & 1 & 1 & 1 & & 1 & 1 & 1 & 1 & 7 \\
\hline Fighting & 1 & 1 & & & 1 & 1 & 1 & & 5 \\
\hline Lying & 1 & & & 1 & 1 & 1 & 1 & 1 & 6 \\
\hline Truant & 1 & 1 & 1 & 1 & & & & 1 & 5 \\
\hline $\begin{array}{l}\text { Rude behaviour towards } \\
\text { parents }\end{array}$ & 1 & 1 & 1 & 1 & & & & & 4 \\
\hline $\begin{array}{l}\text { Sexual relationship outside } \\
\text { wedlock }\end{array}$ & & 1 & 1 & 1 & & & & & 3 \\
\hline Animal abuse & & 1 & & & & 1 & & & 2 \\
\hline Lesbian & & & 1 & & & & & & 1 \\
\hline Breaking curfew & & & & 1 & 1 & & 1 & 1 & 4 \\
\hline Run away from home & & & & 1 & & & & & 1 \\
\hline
\end{tabular}

Source: Interview Questions Set 2019

The results of the interviews explored the two main themes in this study, namely parental monitoring factors and parental communication factors. The whole theme and subthemes are discussed in detail in Table 3.

Table 3. Themes and sub-themes for factors of parental monitoring and parental communication towards adolescents involved in deviant behaviour in Peninsular Malaysia 


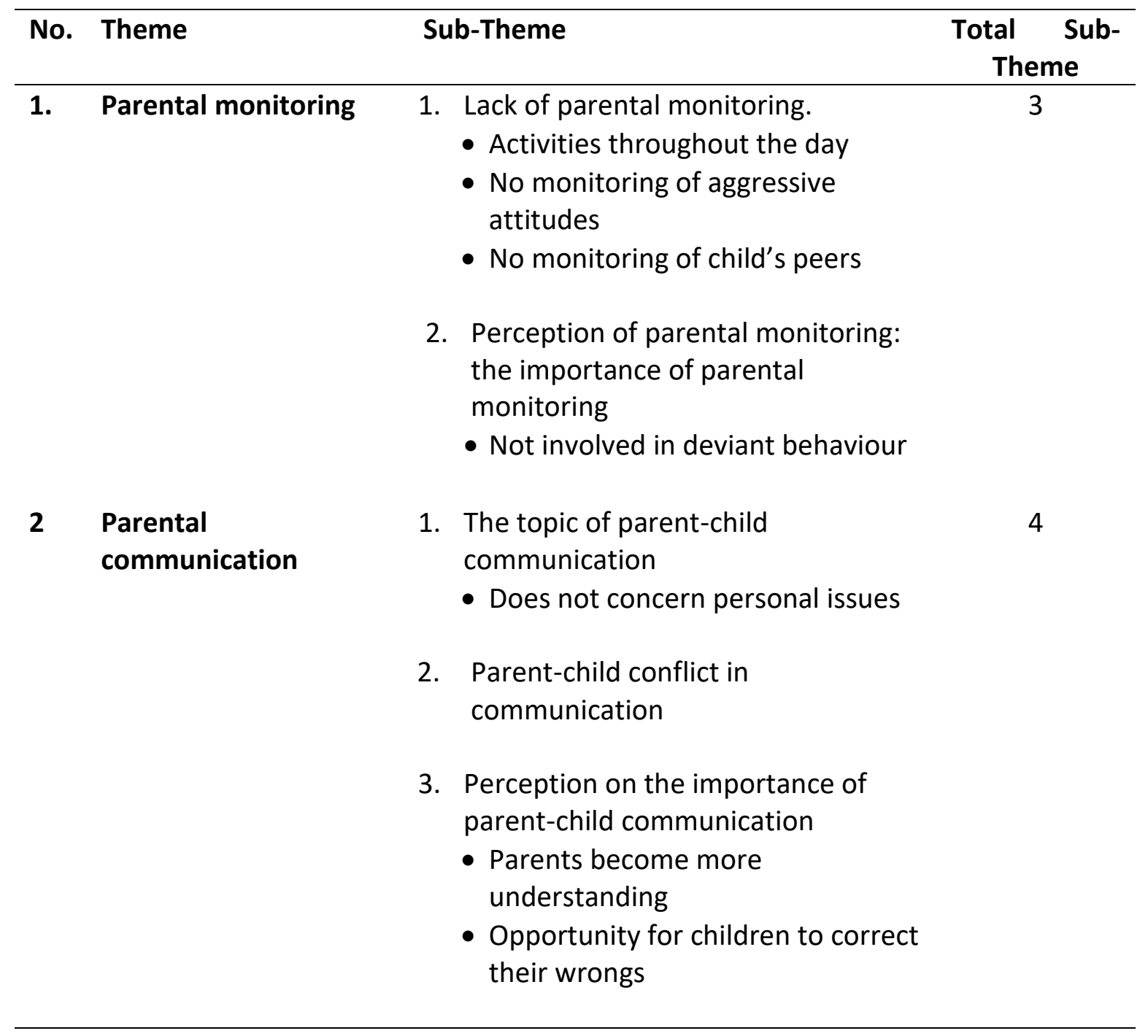

\section{Factors of Parental Monitoring}

Parental monitoring was a major theme studied concurrently with the quantitative review of this study. There were two sub-themes that have been identified from the findings of the main theme of parental monitoring, namely (a) the lack of parental monitoring on their children's activities and (b) the perception of parental monitoring itself.

Based on the sub-theme of the lack of monitoring of children's activities by parents, there were four items, namely children's activities throughout the day, children's aggressive attitude, lack of attention and children's friendships.

Children's activities throughout the day- The lack of parental monitoring first concerned their children's activities throughout the day. Adolescents are more likely to go out at night because the majority of the family members will not be aware of the actions of study respondents out of the house (Transcript K1), (Transcript K4), (Transcript K5), (Transcript K7) and (Transcript K8). They ignored the child's activities after school (Transcript K6) and ignored the child's movements and activities (Transcript K3) and (Transcript K7)

According to Jimenez-Iglesias and Garcia-Moya (2013), parents monitor their children's activities less when the children are developing as adolescents. The lack of 
monitoring of children's activities after school hours indicates the weakness of parents in taking into account the daily activities of their children (Guilamo-Ramos et al., 2010). Thus, monitoring children's activities regardless of time is part of parents 'efforts to know children's movements, what they are doing, and to know what children are keeping secret (Stattin \& Kerr, 2000). The researchers of this study argue that these findings indicate that adolescents who commit deviant behaviours have less parental monitoring, insensitive parental attitudes and careless in paying attention to the developmental process of adolescents.

No monitoring of children's aggressive attitudes- Next is no monitoring of children's aggressive attitudes that is, parents do not take into account the child's devious schemes to avoid from parental monitoring, especially strict parents who limit the movement of children's activities. Aggressive behaviours shared by the respondents include being willing to endanger themselves by walking into bushes and cheating to get out of the house (Transcript K4). In addition, there were also respondents who escaped and felt free by exhibiting violent aggressive behaviours (Transcript K1) (Transcript K8).

These actions indicate that parents who are less aware of the aggressive attitudes of their children make them more courageous to act out deviant behaviours. Studies have found that the lack of parental monitoring relates with children's aggressive attitudes (Lee Randolph, 2015). Aggressive attitudes and behaviours that can take form include having feelings of anger, hurting others or objects, insulting, damaging property, and crime (Rozmi, 2014; Espelage et al., 2013). Good parental monitoring will provide good communication settings that can help children feel safe and can reduce the child's aggressive attitude and vice versa (Kliewer et al., 2006)

Lack of monitoring of children's peers- The third item is that lack of parental monitoring of children's peers as one of the causes of adolescents' engagement in deviant behaviours. Good friends will make children act good and the selection of friends who behave negatively will cause children to be easily influenced to act the same way. This was stated by the study participants (Transcript K2) and (Transcript K4). The study of Liuhua Ying et al., (2015) found that good parental monitoring means parents who are sensitive to the choice of their children's friends; because in adolescence, they spend more time with friends compared to family. During the period of adolescent, proper guidance and monitoring provided by parents are one of the key factors towards positive partner selection (Fosco et al., 2012). It is important in vetting the selection of children's friends so that they are able to choose those who are not involved with deviant behaviours.

Perceptions of parental monitoring is the second sub-theme of the main theme of parental monitoring. The results of the study interviews, found that the respondents expressed two perceptions of the importance of parental monitoring which are to avoid deviant behaviours and get parental attention. The first importance of parental monitoring is that adolescents may not engage in deviant behaviours and parents will deter their children before they begin to engage in deviant behaviours (Transcript K1), (Transcript K2), Transcript K7) and (Transcript K8). If the parents do not monitor their children's activities, then it will get worse (Transcript K4). Parental monitoring also strengthen the relationship between parents and children (Transcript K3) and (Transcript K6).

Caldwell et al (2006); Meadows et al (2002) found that adolescents have a perception that if parents monitor their child's activities and provide affection, it can avoid adolescents 
from engaging in deviant behaviours. Adolescents who receive good monitoring and attention are more open to informing their activities with their parents (Keijsers, 2015). This shows that adolescents need emphatic monitoring and attention for them to train their own thoughts and behaviours to act more positively. Adolescents are accepting of parental monitoring of their activities at any time to ensure that they are not engaged in problematic behaviours (Caprara et al., 2005).

\section{Factors of Parental Communication}

Parental communication was the second major theme identified by this study. The results of the interviews found that there were three sub-themes that indicated the problems among respondents in communicating with parents. The sub-themes identified were (1) the topic of parent-child communication, (2) communication conflict and perceptions of the importance of parent -child communication.

The first sub-theme in the main theme of parental communication is the topic of parent-child communication. The topic of communication devoid of personal issues is the most common problem identified by the respondents. The majority of the respondents in this study stated that they did not discuss personal issues with their parents, instead, they kept the problems they faced (Transcript 1), (Transcript 2), (Transcript 3), (Transcript 4), (Transcript 5), (Transcript 7), (Transcript 8).

Studies have found that a good parent-child relationship is when adolescents feel confident and safe to share personal matters with their parents; and this will indirectly increase feelings of happiness among family members (Aziyah et al., 2015). This is a positive factor that encourages adolescents to improve good coping skills (Noller \& Callan, 1991). This is because, the communication patterns exhibited by parents greatly influence children's lives because it will shape the child's behaviours either positively or negatively (Galvin et al., 2015) .Thus, the confidence to tell personal issues to parents is part of positive communication as it helps adolescents develop problem-solving pathways they experience without having to engage with social symptoms .

The second sub-theme is the conflict in communication that occurs between parents and children. The conflict in communication caused the children to feel that their lives were incomplete due to no communication feedback between parents and children (Transcript K3). The parents did not ask what their wants and problems were (Transcript K4). They were afraid to communicate with parents because they will suspect them partaking in drug abuse and engaging in deviant activities (Transcript K1) and (Transcript K5). The conflicts in communication perhaps occurred because children did not get support from parents and this caused them to be more comfortable communicating with outsiders. Past studies have found that conflicts occur between parents and children due to lack of social support between families and not paying attention to serious issues (Koerner \& Fitzpatrick, 1997). Even negative experiences that occur in the family also cause conflict to occur in relationships within those family members (Koerner \& Fitzpatrick, 1997). This clearly shows that less communicative families can cause children to be disinterested in sharing problems with parents and they are more comfortable to communicate problems with peers (Aziyah et al., 2015). 
The result of the study for the subtheme of parent-child communication stressed the importance of the adolescent's perception of communication in the family, especially with parents. There are two perceptions of the importance of parental communication with children expressed by the respondents namely parents can understand children and children's opportunities to correct mistakes.

Parents can understand children- The first item on the perception of the importance of parental communication is that the respondents stated that communication makes parents better understand their children. Respondents also stated that parent-child communication is mainly the responsibility of parents (Transcript K1). Further, parents also need to realize that family is a source of strength and they should better understand children's problems (Transcript K2). Moreover, when a parent does not empathize and show understanding, the respondents seek freedom to move on their own and cause them to solve problems in the wrong way (Transcript K4) and Transcript (K8). The responses clearly show that when parents understand and communicate effectively with children, it makes adolescents feel loved because they feel that their parents understand their struggle. The study of Fitzpatrick and Koerner (2005) found that children are constantly interpretating the behaviours of family members either verbally or non-verbally based on the way the family communicates. If family members frequently converse with children, it makes them more confident to discuss their feelings to their parents (Keaton \& Kelly, 2008). However, if parents give less love and spend less time with children, adolescents are more comfortable communicating with their friends than family (Meadow \& Blacher, 2002).

Opportunity for children to correct mistakes- The second item is the opportunity for children to correct mistakes. Correcting mistakes is vital so that children know of their mistakes based on the response, advice and reprimand by parents (Transcript K2) and (Transcript K8). Two-way communication between parents and children will have a positive effect whereby the children are able to understand and evaluate their behaviours and subsequently identify them as good or bad. According to Grover (1998), parental intervention on children's affairs through communication can have a positive effect on family functioning. Parents who practice effective communication can help deviant adolescents correct their mistakes and be more careful with their actions. This two-way relationship between parents and children is able to help the emotional development of adolescents and at the same time make adolescents able to understand the actions they perform (Nakheaa et al., 2017; Ennett at al., 2001).

\section{Discussions}

This section discusses the third objective of the study which is the integration for the comparison of the results of the two data (quantitative and qualitative) based on the Simultaneous Triangulation Design. The quantitative and qualitative data were collected simultaneously and the results of the study are analysed separately and later compared. This method is intended to obtain different data in the same title (Almeida, 2018).

\section{Discussion of data integration for parental monitoring factors}

Table 4 shows the integration results for the parental monitoring factors in this study. 
Table 4. Results of the integration of factors of parental monitoring

\begin{tabular}{|c|c|c|}
\hline $\begin{array}{l}\text { QUANTITATIVE } \\
\text { DATA }\end{array}$ & QUALITATIVE DATA & $\begin{array}{l}\text { DATA } \\
\text { INTERGRATION }\end{array}$ \\
\hline $\begin{array}{l}\text { There was a } \\
\text { significant } \\
\text { negative } \\
\text { relationship } \\
\text { between parental } \\
\text { monitoring and } \\
\text { deviant behavior. } \\
\text { The lesser the } \\
\text { parental } \\
\text { monitoring the } \\
\text { higher the deviant } \\
\text { behaviours of } \\
\text { adolescents. }\end{array}$ & $\begin{array}{l}\text { Sub-theme 1: Lack of parental monitoring } \\
\text { of children's activities. } \\
\text { - Children's Activities throughout the day } \\
\text { (movement at night, after school activities, } \\
\text { not paying attention to the child's } \\
\text { movements and activities) } \\
\text { - No monitoring of the child's aggressive } \\
\text { attitude } \\
\text { (walking in the bushes and cheating, freeing } \\
\text { himself by force) } \\
\text { - Lack of monitoring peer influence on their } \\
\text { children } \\
\text { Sub-theme 2: Perceptions of parental } \\
\text { monitoring } \\
\text { - The importance of parental monitoring } \\
\text { (Not involved in deviant behaviours, } \\
\text { improvement in self-esteem by getting } \\
\text { parental attention) }\end{array}$ & $\begin{array}{l}\text { The integration of } \\
\text { both data of the } \\
\text { study found that } \\
\text { they are parallel. } \\
\text { Qualitative data } \\
\text { support the } \\
\text { quantitative data. }\end{array}$ \\
\hline
\end{tabular}

As a result of data integration, it was found that both data are parallel for the factor of parental monitoring. Namely, the lack of parental monitoring makes children more vulnerable to deviant behaviours. These results indicate that the qualitative data is in support of the quantitative data.

Parents or families are the main influences in the formation of adolescent behaviours. This is because during the growth and the formation of adolescent behaviours are dependent on the pattern of the environment from the surrounding. According to Andres et al (2013) found negative adolescent environmental patterns will cause them to easily engage in risky behaviours such as drug abuse, sexual behaviour and violence. Based on this pattern, parental monitoring and knowledge of children's behavioural development are important elements for adolescents to grow up with more positive behaviours (Dishion \& McMahon, 1998). Thus, parental monitoring of children's actions is one of the important factors of the family environment that needs to be considered. This is to ensure the development of children's behaviour is in a positive direction and does not deviate from societal norms.

\section{Discussion of data integration for parental communication factors}

Table 5 shows the results from the integration of data for parental communication factors in this study.

Table 5. Results of the integration of factors of parental communication

\begin{tabular}{|c|c|c|}
\hline $\begin{array}{c}\text { Quantitative } \\
\text { data }\end{array}$ & Qualitative data & Data integration \\
\hline
\end{tabular}




\begin{tabular}{|c|c|c|}
\hline $\begin{array}{l}\text { There was no } \\
\text { significant } \\
\text { relationship } \\
\text { between } \\
\text { parental } \\
\text { communication } \\
\text { and adolescent } \\
\text { deviant } \\
\text { behavior. }\end{array}$ & $\begin{array}{l}\text { Sub-theme 1: Topics of parent-child } \\
\text { communication } \\
\text { - Topics of communication does not concern } \\
\text { personal issues. } \\
\text { Sub-theme 2: conflict in parent-child } \\
\text { communication } \\
\text { Sub-theme 3: perception on the importance } \\
\text { of parent-child communication } \\
\text { - Parents can understand children } \\
\text { - Opportunities for children to right their } \\
\text { wrongs }\end{array}$ & $\begin{array}{l}\text { Integration between } \\
\text { the two data shows } \\
\text { that they are not in } \\
\text { parallel. } \\
\text { However, qualitative } \\
\text { data shows that } \\
\text { parents who do not } \\
\text { practice good } \\
\text { communication with } \\
\text { children is among } \\
\text { the factors that } \\
\text { contribute to } \\
\text { adolescent deviant } \\
\text { behaviours. }\end{array}$ \\
\hline
\end{tabular}

The results from the data in integration indicates that the qualitative and quantitative data differ. Quantitative data indicates that parental communication with children has no relationship with deviant behaviours. This means that parental communication has no relationship on adolescent involvement with deviant behaviours. In contrast, qualitative data shows that adolescents who do not communicate with parents among the reasons they are involved with deviant behaviours. This suggests that the frequency of parent-child communication is closely related to the prediction of adolescent deviant behaviours (Guilamo-Ramos et al., 2006). These results indicate that the qualitative data does not support quantitative data.

Qualitative data of the study shows that when children do not express personal problems, it may result in communication conflicts between parents and children. Furthermore, adolescence who often rejects parental decisions are more prone to deviant behaviours. The nature of communication shown here is a form of conversational orientation communication that is not encouraged (Osredkar, 2012). Conversational-oriented communication forms refer to the frequency of parent-child communication, openmindedness in communicating, children encouraged to express feelings, decisions discussed together between parent and child, and enjoyable daily routine communication (Fitzpatrick \& Richie, 1994). Therefore, if this form of conversational orientation communication is not practiced between parents and their children; it makes it easier for the child to communicate with outsiders rather than their parents (Aziyah et al., 2015). In fact, children who lack communication with parents about their activities show susceptibility to deviant behaviors (Keijsers, 2015). On the other hand, if this conversation orientation is encouraging between parent and child, it will improve interpersonal communication and the development of conflict management that occurs throughout adolescents (Witt \& Messersmith, 2008). Interpersonal communication is important as it can influence self-development, psychology and success influence the environment more positively (Patton \& Giffin, 1981).

\section{Conclusion}

In conclusion, deviant behaviours among adolescents in Peninsular Malaysia should be curbed earlier before adolescents grow into adulthood. The formation of positive behaviours, 
emotions and thoughts of adolescents can produce future generations who are more useful, successful, and can contribute to family and society. Therefore, parental monitoring factors play a very important role in ensuring that children's daily activities are activities that help improve the development of behaviours in a positive direction and accepted by the society. Parental communication factors also play a major role in guiding children to form positive behaviours. Clear, friendly and considerate communication make children more comfortable to express the problems they face to their parents instead of outsiders. Good communication will instil a sense of trust in children to parents, and at the same time this can foster a good relationship between parents and children.

The theoretical implications of this study found that the main factor that contributes a significant deviant behavior among adolescent based on the family institution is the role of parents. Proper education by parents such as monitoring children, providing religious education, the ability of haning effective two-way communication with the children and parents who are able to indentify children's behavior may provide balance growth of children. Moreover, it also encourages them to be more mature in terms of thoughts, behavior and better emotional state. On contrary, if the parents fail to show their responsibility it will affect the children as they will be easily influenced by their growth environment. Thus, the theory is being proved where the family is the main source that contributes to the children's emotional growth in evaluating positive values.

The next implication of the research that can create an impact for Jabatan Kebajikan Masyarakat Malaysia (JKM). In line with the objective of Sekolah Tunas Bakti, an instituation supervised by JKM is established to educate children to build up positive attitudes, form strong personalities and equip them with sufficient competencies to enable them to live independently in society. The results of this study, may be used by JKM to organize more programs that involve parents and children. Beside, parents also will have more exposure about adolescents' growth that makes it easier for them to understand their children.

Based on the research some limitations were identified that may help for future researchers. The focus of these research is upon two variables which are the factor of parental monitoring and parental communication, I hope future researcher will give more focus on family relationship that involve parents and also siblings. Every family members including siblings also affect deviant behavior among adolescents. Besides that, this is a mix-method design that uses using the concurrent triangulation design. Thus, it is recommended for future researchers to run the research focusing on qualitative design with dual level method. Firstly, by using non-verbal to investigate the actual informants behaviour and secondly, by interviewing the informants where it will give a full picture of the observations. This methodology may provide better and accurate view of actual reasons behind inappropriate behaviour of adolescents by choosing to be deviant.

\section{Acknowledgement}

This research received no specific grant from any funding agency in the public, commercial or not-for-profit sectors.

\section{Corresponding Author}

Salina Nen

Faculty of Social Sciences and Humanities, Universiti Kebangsaan Malaysia 


\section{References}

Andres, V. M., Remesal, C. R., Torrico, L. E., \& Salazar, T. I. C. (2013). Impacto de acciones formativas en la percepción de riesgo de jóvenes universitarios: Estudio preliminar [Impact of training actions in the risk perception of university students: A preliminary study]. Global Health Promotion, 20(3), 83-93.

Barnes, G. M., Joseph H. H., Welte, J. W., Farrell, M. P., \& Barbara, A. D. (2006). Effects of Parental Monitoring and Peer Deviance on Substance Use and Delinquency. Journal of Marriage and Family, 68, 1084-1104.

Borawski, E. A., levers-Landis, C. E., Lovegree, L. D., \& Trapl, E. S. (2003). Parental Monitoring, Negotiated Unsupervised Time, and Parental Trust: The Role of Perceived Parenting Practices in Adolescent Health Risk Behaviors. J Adolesc Health, 33(2), 60-70.

Caldwell, R. M., Beutlerb, L. E., Rossc, S. A., \& Silverd, N. C. (2006). Brief report: An examination of the relationships between parental monitoring, self-esteem and delinquency among Mexican American male adolescents. Journal of Adolescence. 29, 459-464.

Caprara, G. V., Pastorelli, C., Regalia, C., \& Scabini, E. (2005). Impact of Adolescents' Filial SelfEfficacy on Quality of Family Functioning and Satisfaction. Journal Of Research On Adolescence,15(1), 71-97.

Creswell, J. W. (2009). Research Design: Qualitative, Quantitative and Mix Methods Approach (3 rd ed.). SAGE Publication, Inc.

Creswell, J. W. (2014). Research Design: Qualitative, Quantitative and Mix Methods Approach (4 th ed.). SAGE Publication, Inc.

Delibalt, V. V., Degtyaryov, A. V., Dozortseva, E. G., Chirkina, R. V., Dvoryanchikov, N. V., \& Pimonov. (2017). Evaluation of cognitive functions, personality and regulatory sphere in minors with deviant and delinquent behavior within the authority of the psychological, medical and educational committee. International Journal of Cognitive Research in Science, Engineering and Education, 5(2), 107-118. http://dx.doi.org/10.5937/IJCRSEE1702107D

Dishion, T. J., \& McMahon, R. J. (1998). Parental monitoring and the prevention of child and adolescent problem behavior: A conceptual and empirical formulation. Clinical Child \& Family Psychology Review, 1(1), 61.

Dishion T. J., Capaldi, D. M., Spracklen, K. M., \& Li, F. (1995). Peer ecology of male adolescent drug use. Development and Psychopathology, 7, 803-824.

Dvoryanchikov, N. V., Bovina, B. I., Delibalt, V. V., Dozortseva, E. G., Bogdanovich, N. V., \& Rubtsova, O. N. (2020). Deviant online behavior in adolescent and youth circles: in search of a risk assessment model. International Journal of Cognitive Research in Science, Engineering and Education (IJCRSEE), 8(2), 105-119.

Ennett, S. T., Bauman, K. E., Foshee, V. A., Pemberton, M., Katherine, A., \& Hicks, K. A. (2001). Parent-Child Communication about Adolescent Tobacco and Alcohol Use: What Do ParentsSay and Does It Affect Youth Behavior?. Journal of Marriage and Family, 63(1), 48-62.

Fitzpatrick, M. A., \& Koerner, A. F. (Eds). (2005). The Evolution of Key Mass Communication Concepts. Hampton Press.

Fosco, G. M., Stormshak, E. A., Dishion, T. J., \& Winter, C. E. (2012). School as Predictors of Early Adolescent Problem Behavior. Journal of Clinical Child \& Adolescent Psychology, 41(2), 202-213. DOI: 10.1080/15374416.2012.651989 
Galvin, M. K., Braithwaite, O. D., \& Baylund, L. C. (2015). Family Communication: Cohesion and change. ( $9^{\text {th }}$ ed.). Pearson Education Inc.

Grover, P. (1998). Preventing substance abuse among children and adolescents: Familycentered approach- es. Washington: Department of Heath and Hu- man Services, Substance.

Guilamo-Ramos, V., Jaccard, J., Dittus, P., \& Bouris, A. M. (2006). Parental Expertise, Trustworthiness, and Accessibility:Parent-Adolescent Communicationand Adolescent Risk Behavior. Journal of Marriage and Family. 68(5), 1229-1246.

Guzman, T. D., \& Pohlmeier, L. A. (2014). High-Risk Behaviors in Youth. Families, Adolescene and Youth. https://extensionpublications.unl.edu/assets/pdf/g1715.pdf

Institut Penyelidikan Pembangunan Belia Malaysia. (2016, Disember 26). Kajian Gejala Sosoal Di Kalangan Belia Malaysia. http://ippbm.gov.my/dokumen/faktabelia/ 11.Tingkahlaku.pdf.

James, J., Hart, B., \& Tonya, D. (2005). Peer Influences on Risk Behavior: An Analysis of the Effects of a Close Friend. Developmental Psychology, 41 (1), 135-147.

Keaton, J., \& Kelly, L. (2008). Emotional Intelligence as a Mediator of Family Communication Patterns and Reticence. Communication Reports, 21(2), 104-116.

Keijsers, L. (2015). Parental Monitoring And Adolescent Problem Behaviors: How Much Do We Really Know? International Journal of Behavioral Development, 1-11.

Kliewer, W., Murrelle, L., Prom, E., Ramirez, M., Obando, P., \& Sandi, L. (2006). Violence exposure and drug use in Central American youth: Family cohesion and parental monitoring as protective factors. Journal of Research on Adolescence, 16, 455-478.

Koerner, A. F., \& Fitzpatrick, M. A. (1997). Family type and conflict: The impact of conversation orientation and conformity orientation on conflict in the family. Communication Studies, 48, 59-75.

Liuhua, Y., Fengling, M., Huahua, H., Xiaolin, G., Chuansheng, C., Fen, X. (2015). Parental Monitoring, Parent-Adolescent Communication, and Adolescents' Trust in Their Parents in China. PLoS ONE, Journal Pone, 10(8). https://doi.org/10.1371/journal.pone.0134730

Lytle, L. A., Birnbaum, A., Boutelle, K., \& Murray, D. M. (1999). Wellness and risk communication from parent to teen: the "Parental Energy Index". Health Education, 99 (5), 207 - 214. http://dx.doi.org/10.1108/09654289910294732.

Meadows, R. J., \& Blacher, J. H. (2002). Difficult teens: A parent's guide for coping. Ventura, CA:Meadow Oaks Press.

Mena, M. P., Dillon, F. R., Mason, C. A., \& Santisteban, D. A. (2008). Communication About Sexually-Related Topics Among Hispanic Substance-Abusing Adolescents and Their Parents. J Drug Issues, 38(1), 215-234. doi:10.1177/002204260803800110

Miller, K. S., Kotchick, B. A., Dorsey, S., Forehand, R., \& Ham, A. Y. (1998). Family communication about sex: What are parents saying and are their adolescents listening? Family Planning Perspectives, 30, 218 - 222.

Muhwezi, W. W., Katahoire, A. R., Banura, C., Mugooda, H., Kwesiga, D., Bastien, S. \& Klepp, K. I. (2015). Perceptions and experiences of adolescents, parents and school administrators regarding adolescent-parent communication on sexual and reproductive health issues in urban and rural Uganda. Reproductive Health, 12-110. DOI 10.1186/s12978-015-0099-3.

Noller, P., \& Callan, V. J. (1991). The Adolescent in the Family. Routledge. 
Osredkar, P. (2012). The Relationship Between Family Communication Patterns and an Individual's Emotional Intelligence. University of Portland, Department of Communication Studies: Spring.

Ritchie, L. D., \& Fitzpatrick, M. A. (1990). Family communication pattern measuring intrapersonal perception of interpersonal relationship. Communication Research, 17(4), 532-545.

Ali, R. (2010). Meramal Tingakh Laku Sosial dan Agresif Kanak-KanakYang Memerlukan Pemeliharaan dan Perlindungandi Rumah Kanak-Kanak Tengku Ampuan Aminah Fatimah, Kuantan. [Unpublished M.Appl.Psy.thesis]. Universiti Kebangsaan Malaysia.

Alboukordi, S., Nazari, A. M., Nouri, R., \& Sangdeh, J. K. (2012). Predictive Factors for Juvenile Delinquency: The Role of Family Structure, Parental Monitoring and Delinquent Peers. International Journal of Criminology and Sociological Theory, 5(1), 770-777.

Smith, P. K., \& Thompson, D. (1991). Practical Approaches to Bullying. David Fulton.

Stattin, H., \& Kerr, M. (2000). Parental monitoring: a reinterpretation. Child Development, 71(4), 1072-1085. 